\title{
Preface: European Commission's Marie Curie Action ECOSUMMER
}

\author{
Graham J. Pierce • Vasilis D. Valavanis • \\ M. Begoña Santos $\cdot$ Julio M. Portela
}

Published online: 24 May 2011

(C) Springer Science+Business Media B.V. 2011

Marie Curie (born Marja Skłodowska) was the first person to win Nobel Prizes in two sciences (in Physics-1903 and in Chemistry-1911). She moved from her native Poland to study and pursue a scientific career in France and became well known for her dedication, persistence and passion for work. Her scientific achievements are all the more remarkable for taking place at a time in history when conditions for research and in particular for women in science were often difficult. She was well liked by both her colleagues and friends, to whom she was able to communicate the passion she felt for her work.

Guest editors: Graham J. Pierce, Vasilis D. Valavanis, M. Begoña Santos \& Julio M. Portela / Marine Ecosystems and Sustainability

\section{G. J. Pierce}

School of Biological Sciences, University of Aberdeen, Aberdeen, UK

V. D. Valavanis $(\bowtie)$

Marine GIS Lab, Institute of Marine Biological Resources, Hellenic Centre for Marine Research, Heraklion, Greece

e-mail: vasilis@her.hcmr.gr

M. Begoña Santos · J. M. Portela

Centro Oceanográfico de Vigo, Instituto Español de

Oceanografía, Vigo, Spain
Hence, it is fitting that the European Commission named its programme of training awards for young researchers after Madame Curie. Marie Curie Actions provide the opportunity for young researchers to improve their research skills and enhance their career prospects through competitive and intensive efforts, mobility and dedication; characteristics that will always contribute to the establishment of a promising scientific career. Specifically, Marie Curie Initial Training Networks (ITN) promote the mobility of young researchers, between different European countries and into Europe from other parts of the world, an important step that exposes them to a variety of established research centres and universities in order to meet, interact with, and collaborate with other researchers, expand their research ideas and horizons, and develop those character attributes required in the increasingly competitive field of research.

This issue presents some of the scientific output of one such network in the field of marine sciences. ECOSUMMER (ECOsystem approach to SUstainable Management of the Marine Environment and its living Resources) was a 4-year (2006-2009) multihost Training Site for Early-Stage Research Training (EST). Eight universities and research institutes collaborated in the project: the University of Aberdeen (UABDN, UK), the Fisheries Research Services Marine Laboratory (FRS, UK), the Scottish Association for Marine Science (SAMS, UK), the Hellenic Centre for Marine Research (HCMR, GR), the Instituto Español de Oceanografía (IEO, ES) with 
its Centro Oceanográfico in Vigo, the University of Vigo (UVIGO, SP), the University of the Aegean (UAEGEAN, GR) and the Instituto de Investigaciones Marinas (IIM/CSIC, ES). This network of research and education centres provided research topics and training for 23 early-stage researchers for training periods lasting between 3 months and 3 years. These early-stage researchers were selected from a total of 89 applications from all over the world, financing researchers from the UK, France, Spain, Italy, Greece, Portugal, Germany, Denmark, the Netherlands, Chile and Mexico. Now, more than 1 year after the completion of their training and research, all trainees continue to work in the academic and private sectors in Europe and overseas.

The special issue includes 19 scientific papers on marine subjects, including topics in biodiversity and genetics, species-environment interactions, fisheries, aquaculture, morphometrics and ecosystem modelling. The project held a final conference on "Marine Ecosystems and Sustainability (MESS)" in Aberdeen in December 2009. In addition to papers from the Marie Curie researchers themselves, the special issue includes contributions based on invited talks at the MESS conference and contributions from other students and colleagues who participated in project activities. These papers are broadly focused on the diversity of marine ecosystems and their sustainable utilization.

We wish to acknowledge our Project Officer in the Directorate-General for Research (Brussels, Belgium), Frank Marx, for his extensive help and support over $3 \frac{1}{2}$ years, also Kamila Partyka, Przemyslaw Jankowski, Evert Van den Broeck and Monika Dudek, who handled the later stages of the project. We thank the many scientists, acting as anonymous referees, who provided constructive comments on earlier versions of the articles in this issue (reviewers' names are listed below). We are grateful to Martine van Bezooijen (Springer) and Koen Martens (Royal Belgian Institute of Natural Sciences) for providing the opportunity to publish this special issue in Hydrobiologia. Finally, we would like to thank all the ECOSUMMER researchers and their supervisors for their contributions to the project and to this special issue (researchers' names and their projects are listed below). We hope that readers of this special issue of Hydrobiologia will find it useful and that it inspire further work on the sustainable use of marine ecosystems.

\section{List of reviewers}

\author{
Jurgen Alheit \\ Paula Alvarez \\ Alexander Arkhipkin \\ Christos Arvanitidis \\ Daniela Banaru \\ Alberto Basset \\ Janet Brown \\ Ratana Chuenpagdee \\ Alberto Garcia \\ Elizabeth Gosling \\ Angel Guerra \\ Belgin Hossu \\ Jorgen Hylleberg \\ Stelios Katsanevakis
}

Giorgos Koumoundouros
Vladimir Laptikhovsky
Evgenia Lefkaditou
Colin MacLeod
Athanassios Machias
Corinne Martin
Paloma Martin
Joan Moranta
Ada Natoli
Ioannis Nengas
Andreas Palialexis
Miguel Palmer
Kim Parsons
Joao Pereira

Benjamin Planque

Andrew Pullin

Dionysios Raitsos

Javier Ruiz

Ana Sabates

Konstantinos Stergiou

Allan Stoner

George Tserpes

Athanassios Tsikliras

Roger Villanueva

Esin Yalçin

Alain Zuur 


\section{List of researchers}

List of researchers, their country of origin, project titles, and institutions involved under the Marie Curie Action ECOSUMMER (2006-2009)

\begin{tabular}{|c|c|c|}
\hline Fellow name & Project title & Hosts \\
\hline Angela Ribeiro (Portugal) & $\begin{array}{l}\text { Effective population size of the Atlantic salmon (Salmo salar) } \\
\text { population inhabiting the river Eo (Spain) }\end{array}$ & UVIGO \\
\hline Beatriz Guijarro (Spain) & $\begin{array}{l}\text { Assessment of the slope trawl fishery resources off the Balearic } \\
\text { Islands (western Mediterranean) using experimental survey } \\
\text { data: from single to multi-species approach }\end{array}$ & HCMR \\
\hline Christian Lønborg (Denmark) & $\begin{array}{l}\text { Resolving the importance of dissolved organic nitrogen (DON) } \\
\text { and dissolved organic phosphorus (DOP) in Marine coastal } \\
\text { waters }\end{array}$ & $\begin{array}{l}\text { SAMS } \\
\text { IIM }\end{array}$ \\
\hline Consuelo Hermosilla (Chile) & $\begin{array}{l}\text { Population structure of Octopus vulgaris: combination of } \\
\text { ageing, morphometric, genetics and GIS methods }\end{array}$ & $\begin{array}{l}\text { IIM } \\
\text { HCMR } \\
\text { UAEGEAN } \\
\text { UVIGO }\end{array}$ \\
\hline Evangelina Gontikaki (Greece) & The role of organic matter quality in deep-sea carbon cycling & $\begin{array}{l}\text { UABDN } \\
\text { SAMS }\end{array}$ \\
\hline Fiona Read (UK) & $\begin{array}{l}\text { Understanding marine mammal interactions with fisheries in } \\
\text { Galician waters, NW Spain }\end{array}$ & $\begin{array}{l}\text { IIM } \\
\text { IEO }\end{array}$ \\
\hline Fleur Visser (Netherlands) & $\begin{array}{l}\text { Spatial distribution of cetaceans at the Azores: Species' and } \\
\text { niche diversity in a remote marine area }\end{array}$ & UAEGEAN \\
\hline Gema Martínez (Spain) & $\begin{array}{l}\text { Spatio-temporal distribution of pelagic fisheries in Galician } \\
\text { coast using GAMs and other statistical tools }\end{array}$ & $\begin{array}{l}\text { UAEGEAN } \\
\text { HCMR }\end{array}$ \\
\hline Iñigo Martinez Saez (Spain) & $\begin{array}{l}\text { Fished Grounds to Oil Platform Refugium: Temporal changes } \\
\text { in Fish Assemblage }\end{array}$ & FRS \\
\hline Isidora Katara (Greece) & $\begin{array}{l}\text { Atmospheric and oceanic teleconnection patterns and their } \\
\text { impact on fisheries-environment interactions }\end{array}$ & UABDN \\
\hline Katie Longo (Italy) & $\begin{array}{l}\text { Predator-prey interactions and indicators of the impact of } \\
\text { fisheries on fish species diversity }\end{array}$ & $\begin{array}{l}\text { UABDN } \\
\text { HCMR }\end{array}$ \\
\hline Martina Stritmatter (Germany) & $\begin{array}{l}\text { Molecular biology of the Ectocarpus/Eurychasma host- } \\
\text { pathogen interaction }\end{array}$ & $\begin{array}{l}\text { SAMS } \\
\text { UAEGEAN }\end{array}$ \\
\hline Neil Fletcher (UK) & $\begin{array}{l}\text { Spatio-temporal analysis of pelagic species in the Aegean Sea } \\
\text { in relation to environmental factors and feeding preferences }\end{array}$ & $\begin{array}{l}\text { HCMR } \\
\text { UAEGEAN }\end{array}$ \\
\hline Patrícia Joana Dias (Portugal) & $\begin{array}{l}\text { Evolutionary genetics of the Mytilus edulis complex in } \\
\text { Scotland }\end{array}$ & $\begin{array}{l}\text { FRS } \\
\text { HCMR } \\
\text { UABDN }\end{array}$ \\
\hline Rebeca Rodriguez (Mexico) & $\begin{array}{l}\text { Population structure of Helicolenus dactylopterus } \\
\text { dactylopterus in the North East Atlantic and Mediterranean } \\
\text { using traditional and geometric morphometric techniques }\end{array}$ & $\begin{array}{l}\text { IIM } \\
\text { IEO }\end{array}$ \\
\hline Ricardo Fernandes (Portugal) & $\begin{array}{l}\text { Development of a GIS-based tool for interfacing and } \\
\text { manipulation of time series 4D marine datasets }\end{array}$ & HCMR \\
\hline Ruth Fernandez (Spain) & $\begin{array}{l}\text { Bottlenose dolphin, Tursiops truncatus (Montagu 1821), } \\
\text { trophic ecology and population structure in Galicia, NW } \\
\text { Spain }\end{array}$ & $\begin{array}{l}\text { UAEGEAN } \\
\text { HCMR } \\
\text { UABDN }\end{array}$ \\
\hline Sabine Goetz (Germany) & $\begin{array}{l}\text { Analysis of the interactions of cetaceans with fisheries and } \\
\text { aquaculture in Galicia }\end{array}$ & IEO \\
\hline
\end{tabular}


continued

\begin{tabular}{|c|c|c|}
\hline Fellow name & Project title & Hosts \\
\hline Sarah Faulwetter (Germany) & $\begin{array}{l}\text { Biodiversity resources management: virtual information } \\
\text { depository }\end{array}$ & $\begin{array}{l}\text { HCMR } \\
\text { UAEGEAN }\end{array}$ \\
\hline Sonia Mehault (France) & $\begin{array}{l}\text { Integrating the reproductive potential concept into stock } \\
\text { assessment and implication for management }\end{array}$ & $\begin{array}{l}\text { IIM } \\
\text { IEO }\end{array}$ \\
\hline Susana Rivero Rodriguez (Spain) & $\begin{array}{l}\text { Evaluation of the environmental impacts of Mediterranean fish } \\
\text { farming using life cycle assessment }\end{array}$ & HCMR \\
\hline Tania Santos Diniz (Portugal) & $\begin{array}{l}\text { Identifying and mapping the overlap in resource exploitation } \\
\text { between marine mammals and fisheries along the Galician } \\
\text { coast }\end{array}$ & UVIGO \\
\hline Vagelis Spyrakos (Greece) & $\begin{array}{l}\text { Water quality analysis methods aimed to study and detect } \\
\text { HABs on the Galician coast }\end{array}$ & UVIGO \\
\hline
\end{tabular}

